\title{
Somatotype Profiles of Male and Female Montenegrin Judokas
}

\author{
Perfiles Somatotípicos de Judokas Montenegrinos Masculinos y Femeninos
}

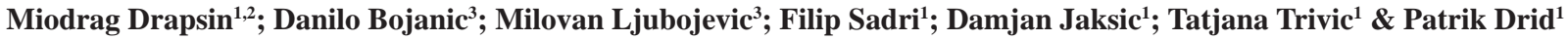

DRAPSIN, M.; BOJANIC, D.; LJUBOJEVIC, M.; SADRI, F.; JAKSIC, D.; TRIVIC, T. \& DRID, P. Somatotype Profiles of Male and Female Montenegrin Judokas. Int. J. Morphol., 38(5):1244-1249, 2020.

SUMMARY: The objective of this research was to establish the anthropometric characteristics and somatotype profiles of Montenegrin male and female judokas, divided by weight categories. The sample was composed of 170 Montenegrin judokas, 92 male judo athletes ( $21.8 \pm 3.9$ years) and 78 female judo athletes $(20.5 \pm 3.1$ years). All athletes were of national level, divided by official weight categories. This study provides normative data of anthropometric and somatotype profiles in relation to gender and weight categories of Montenegrin judo athletes. The anthropometric profiles changed according to weight category, whereas, anthropometric parameters were highest in the heaviest category as compared to other weight categories. In the domain of male somatotype profiles, three different types of somatotype in relation to weight category were obtained. The three weight categories were endomorphic mesomorphs (-90 kg, -100 kg, >100 kg), ectomorphic mesomorphs (-60 kg, -73 kg, -81 kg) and judo athletes of -66 kg were mesomorphic ectomorphs. All the female athletes were endomorphic mesomorphs, except for category 52 . Representatives from the $-52 \mathrm{~kg}$ were mesomorphic endomorphs. This study highlights how somatotype profiles of national judo athletes differ between weight categories. It is likely that some changes could be used in applying proper training methods with a focus on the athletes' physical abilities, which could result in a decrease in somatotype diversity among weight categories.

KEY WORDS: Martial arts; Judo; Skinfold thickness.

\section{INTRODUCTION}

Understanding and determining the characteristics of athletes can provide insightful information with regard to what is needed for improving competitive success. Judo is an Olympic combat sport divided in seven weight categories for both males and females. Based on age and weight category, judokas control body mass in order to select a matching category (Drid et al., 2019). Male and female judokas are concerned with attaining and/or maintaining an optimal body weight and composition. Therefore, they usually try to maximize muscle mass and minimize adiposity. Increased body weight can be an advantage only in the heavyweight category. Body structure can play a determining role in the achievement of judo performance (Franchini et al., 2011a; Trivic et al., 2016; Roklicer et al., 2020). In that sense, special attention is directed to the morphological characteristics of elite athletes (Franchini et al., 2012; Drid et al., 2015; Trivic et al., 2020). Somatotype, as a method, describes three components relative to height: Endomorphy, mesomorphy and ectomorphy (Carter \& Heath, 1990). Since judo is determined by strength, muscle mass is a predictor of muscular efficiency and sports performance (Mala et al.,
2017). As such, it is important to determine the somatotype and body composition of athletes. Somatotype profiles vary between the different weight categories (Franchini et al. 2014). Elite male judo athletes expressed profiles related to the mesomorphic, while female judokas presented endomorphic component values nearer to the mesomorphic (Franchini et al., 2011b). Also, the authors found relationships between somatotype and the level of sports achievement (Busko et al., 2017). A database concerning the somatotype profiles of the Montenegrin national team may allow comparisons with athletes from other countries by each category. The aim of the present study was to describe and analyze the anthropometric characteristics and somatotypes of male and female Montenegrin judokas.

\section{MATERIAL AND METHOD}

Subjects. This study consisted of 92 male judo athletes $(21.8$ \pm 3.9 years) and 78 female judo athletes (20.5 \pm 3.1 years). Measurements were taken in April 2018. All testing

\footnotetext{
${ }^{1}$ Faculty of Sport and Physical Education, University of Novi Sad, Novi Sad, Serbia.

${ }^{2}$ Medical Faculty, University of Novi Sad, Novi Sad, Serbia.

${ }^{3}$ Faculty of Sport and Physical Education, University of Montenegro, Niksic, Montenegro.
} 
procedures were conducted during the National Judo camp held in Niksic (Montenegro). Participants were divided into seven official male $(-60 \mathrm{~kg},-66 \mathrm{~kg},-73 \mathrm{~kg},-81 \mathrm{~kg},-90 \mathrm{~kg}$, $-100 \mathrm{~kg}$ and $+100 \mathrm{~kg})$ and female weight categories $(-48$ $\mathrm{kg},-52 \mathrm{~kg},-57 \mathrm{~kg},-63 \mathrm{~kg},-70 \mathrm{~kg}$ and $+78 \mathrm{~kg})$. All participants were divided into weight categories in accordance with their age and sex, as per the International Judo Federation (IJF) rules. All participants took part voluntarily in the study. Participants were familiarized with all of the testing procedures used in the present study. Two graduated students of the Faculty for Sport and Physical Education, University of Montenegro, measured the subjects in the same position. Informed written consent was obtained from each subject, and all procedures were performed in accordance with the Declaration of Helsinki. The study was approved by the local institutional review board (IRB) of the Faculty for Sport and Physical Education, University of Novi Sad (Ref. No. 12/2017; approved on April 1, 2017).

Anthropometrical measurements. The following anthropometric measurements were conducted: Height and body mass, four skinfolds (triceps, subscapular, supraspinale and calf), breadths (humerus and femur diameters) and girths (arm and calf). Body height was determined using a Martin anthropometer (GPM, Switzerland); skinfolds were measured using a John Bull caliper (British Indicator Ltd, UK), accurate to $0.2 \mathrm{~mm}$; girth measurements were acquired with a steel measuring tape and wrist girth and bicondylar diameters of the femur and humerus were measured using a small spreading caliper (SiberHegner, Switzerland).

Statistical analysis. Data are presented as means and standard deviation ( \pm ). One-way ANOVA and Tukey's post hoc tests were used to compare group the differences by weight categories. Effect size (h2) was calculated as well. The level of significance was set at $5 \%$. All analyses were conducted using SPSS statistics software.

\section{RESULTS}

Subjects were measured and weighed at the National Montenegrin camp before a training session. All anthropometric characteristics and somatotype parameters of the male judokas are presented in Table I.

Statistically significant effects in all the anthropometric characteristics and somatotypes of the male judokas were noted. Anthropometric parameters were highest in the heavyweight category as compared to the other weight categories. With an increase in weight, a higher average height was observed. Anthropometric parameters showed a significant linear increase from the lightest to the heaviest weight category. With regard to skinfolds, the first five categories had statistically significant lower values of all the four skinfold measurements when compared with the two heaviest categories.

Also, statistically significant differences in the humerus and femur breadths were mainly found in the heaviest weight category when compared to the other categories. In terms of arm girth and calf girth, a statistically significant linear increase was observed from the lightest to heaviest weight category. Somatotype differences were observed between all of the weight categories.

Statistically significant effects in all of the parameters were noted, except for in the supraspinale skinfold (Table II). With an increase in weight, a higher average height was observed. Anthropometric parameters showed a significant linear increase from the lightest to the heaviest weight category. With regard to skinfolds, statistically significant differences were noted only for the subscapular skinfold in the first four categories, and for the triceps in the $-48 \mathrm{~kg}$ category, as compared to the above $78 \mathrm{~kg}$ category.

Humerus and femur breadths were mainly found in the heaviest weight category when compared to other categories. In terms of breadth and girth, differences were mainly found in all of the weight categories when compared with the $-78 \mathrm{~kg}$ and above $78 \mathrm{~kg}$ categories. Somatotype differences in the female judokas were observed in the mesomorphy and ectomorphy components as compared with those only above $78 \mathrm{~kg}$. Figure 1 presents the somatotype components of the male judo athletes from different weight categories.

Three separate groups by weight category were observed. Somatocharting showed that the three weight categories were endomorphic mesomorphs $(-90 \mathrm{~kg},-100 \mathrm{~kg}$ and $>100 \mathrm{~kg}$ ), ectomorphic mesomorphs $(-60 \mathrm{~kg},-73 \mathrm{~kg}$ and $-81 \mathrm{~kg}$ ) and judo athletes of $-66 \mathrm{~kg}$ were mesomorphic ectomorphs. Athletes from the heaviest category were categorized as an extreme endomorphic mesomorphic type. Figure 2 presents the somatotype components of the female judo athletes from different weight categories.

The heaviest weight category had highest endomorphic and mesomorphic components, but the lowest ectomorphic component. All of the athletes were endomorphic mesomorphs, except for category 52 . Representatives from the $-52 \mathrm{~kg}$ category were mesomorphic endomorphs. 
DRAPSIN, M.; BOJANIC, D.; LJUbOJEVIC, M.; SADRI, F.; JAKSIC, D.; TRIVIC, T. \& DRID, P. Somatotype Profiles of Male and Female Montenegrin Judokas. Int. J. Morphol., 38(5):1244-1249, 2020

Table I. Differences between weight categories of male judokas.

\begin{tabular}{|c|c|c|c|c|c|c|c|c|}
\hline Variable & $\begin{array}{c}-60 a \\
(n=8)\end{array}$ & $\begin{array}{c}-66 \mathrm{~b} \\
(n=13)\end{array}$ & $\begin{array}{c}-73 c \\
(n=16)\end{array}$ & $\begin{array}{c}-81 d \\
(n=16)\end{array}$ & $\begin{array}{c}-90 \mathrm{e} \\
(\mathrm{n}=18)\end{array}$ & $\begin{array}{l}-100^{f} \\
(n=9)\end{array}$ & $\begin{array}{l}>100^{\mathrm{g}} \\
(\mathrm{n}=12)\end{array}$ & Statistics \\
\hline Height & $171.01 \pm 4.29$ & $175.38 \pm 6.28$ & $177.04 \pm 4.19$ & $178.75 \pm 5.20$ & $183.14 \pm 3.86^{\mathrm{a}, \mathrm{b}}$ & $188.87 \pm 8.26 \mathrm{a}^{\mathrm{b}, \mathrm{c}, \mathrm{d}}$ & $186.47 \pm 10.46^{\text {ab,c,c,d }}$ & $\begin{array}{c}\mathrm{F}=10.70 \mathrm{p}=0.00 \\
\mathrm{n} 2=0.43\end{array}$ \\
\hline \multicolumn{9}{|l|}{ Skinfold } \\
\hline Triceps & $5.58 \pm 1.02$ & $7.48 \pm 2.74$ & $7.35 \pm 1.41$ & $6.43 \pm 2.21$ & $7.82 \pm 2.35$ & $8.97 \pm 3.21$ & $11.53 \pm 4.18 \mathrm{a}^{\mathrm{b}, \mathrm{c}, \mathrm{de}}$ & $\begin{array}{c}\mathrm{F}=6.29 \mathrm{p}=0.00 \\
\mathrm{n} 2=0.31\end{array}$ \\
\hline Supraspinale & $6.63 \pm 1.59 \mathrm{f}$ & $6.21 \pm 1.42$ & $7.10 \pm 2.36$ & $6.84 \pm 1.94$ & $6.87 \pm 1.08$ & $13.71 \pm 7.29_{\mathrm{ab}, \mathrm{c}^{\mathrm{c}, \mathrm{de}, \mathrm{g}}}$ & 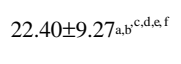 & $\begin{array}{c}F=24.26 p=0.00 \\
\eta 2=0.63\end{array}$ \\
\hline Subsca pular & $7.46 \pm 0.99$ & $7.95 \pm 1.76$ & $8.78 \pm 1.88$ & $10.12 \pm 1.26$ & $10.55 \pm 2.35$ & $13.76 \pm 4.64^{\mathrm{a}, \mathrm{b}, \mathrm{c}, \mathrm{d}, \mathrm{g}}$ & $21.30 \pm 5.355_{\mathrm{a}, \mathrm{b}}^{\mathrm{c}, \mathrm{d}, \mathrm{e}, \mathrm{f}}$ & $\begin{array}{c}\mathrm{F}=33.33 \mathrm{p}=0.00 \\
\mathrm{n} 2=0.70\end{array}$ \\
\hline Calf & $5.98 \pm 1.11$ & $7.74 \pm 3.00$ & $8.11 \pm 2.12$ & $6.43 \pm 2.36$ & $8.57 \pm 3.82$ & $9.13 \pm 2.48$ & $12.04 \pm 4.14 \mathrm{a}^{\mathrm{b}, \mathrm{c}, \mathrm{de}}$ & $\begin{array}{c}\mathrm{F}=5.25 \mathrm{p}=0.00 \\
\mathrm{n} 2=0.27\end{array}$ \\
\hline \multicolumn{9}{|l|}{ Breadth } \\
\hline Humerus & $6.74 \pm 0.68$ & $6.86 \pm 0.55$ & $6.88 \pm 0.75$ & $7.55 \pm 1.14$ & $7.48 \pm 0.79$ & $7.52 \pm 0.49$ & $8.62 \pm 0.98^{\mathrm{a}} \mathrm{a}^{\mathrm{b}, \mathrm{cd}, \mathrm{e}}$ & $\begin{array}{c}\mathrm{F}=7.34 \mathrm{p}=0.00 \\
\eta 2=0.34\end{array}$ \\
\hline Femur & $9.45 \pm 0.60$ & $9.09 \pm 0.97$ & $9.61 \pm 0.30$ & $9.79 \pm 0.44$ & $10.10 \pm 0.41 \mathrm{~b}$ & $10.09 \pm 1.30 \mathrm{~b}$ & $11.00 \pm .99 \mathrm{a}^{\mathrm{b}, \mathrm{bd}, \mathrm{e}}$ & $\begin{array}{c}\mathrm{F}=8.52 \mathrm{p}=0.00 \\
\mathrm{n} 2=0.38\end{array}$ \\
\hline \multicolumn{9}{|l|}{ Girth } \\
\hline Arm & $29.56 \pm 2.21$ & $28.76 \pm 1.81$ & $32.62 \pm 7.16$ & $38.64 \pm 9.89^{b}$ & $38.41 \pm 8.91 \mathrm{~b}$ & $37.91 \pm 2.25$ & $47.31 \pm 12.56^{\mathrm{a}} \mathrm{b,c}$ & $\begin{array}{c}\mathrm{F}=7.72 \mathrm{p}=0.00 \\
\mathrm{n} 2=0.35\end{array}$ \\
\hline Calf & $33.71 \pm 1.39$ & $35.30 \pm 0.91$ & $35.46 \pm 2.63$ & $36.82 \pm 3.13$ & $39.18 \pm 1.84^{\mathrm{a}, \mathrm{b}, \mathrm{c}}$ & $41.67 \pm 1.76^{\mathrm{a}, \mathrm{b}, \mathrm{c}, \mathrm{d}}$ & $45.18 \pm 5.33 \mathrm{a}^{\mathrm{b}, \mathrm{c}, \mathrm{de}}$ & $\begin{array}{c}\mathrm{F}=23.92 \mathrm{p}=0.00 \\
\mathrm{n} 2=0.63\end{array}$ \\
\hline \multicolumn{9}{|l|}{ Somatotypes } \\
\hline Endomorphy & $1.85 \pm 0.37$ & $2.01 \pm 0.59$ & $2.17 \pm 0.49$ & $2.16 \pm 0.46$ & $2.29 \pm 0.52$ & $3.24 \pm 1.41^{\mathrm{a}, \mathrm{b}, \mathrm{c}, \mathrm{d}}$ & $4.71 \pm 1.35^{\mathrm{a}, \mathrm{b}, \mathrm{c}, \mathrm{d}, \mathrm{ef}}$ & $\begin{array}{c}\mathrm{F}=19.87 \mathrm{p}=0.00 \\
\eta 2=0.58\end{array}$ \\
\hline Mesomorphy & $4.34 \pm 1.04$ & $3.70 \pm 1.28$ & $4.56 \pm 1.80$ & $6.41 \pm 2.90^{\mathrm{b}}$ & $6.24 \pm 1.91$ & $5.80 \pm 1.46$ & $9.83 \pm 4.15^{\mathrm{a}, \mathrm{b}, \mathrm{c}, \mathrm{d}, \mathrm{e}, \mathrm{f}}$ & $\begin{array}{c}\mathrm{F}=9.14 \mathrm{p}=0.00 \\
\mathrm{n} 2=0.39\end{array}$ \\
\hline Ectomorphy & $3.44 \pm 1.01 \mathrm{e}^{\mathrm{ffg}}$ & $3.62 \pm 1.20^{\mathrm{d}, \mathrm{e}, \mathrm{f}, \mathrm{g}}$ & $3.03 \pm 0.80^{\mathrm{e}, \mathrm{fg} g}$ & $2.32 \pm 1.01^{\mathrm{g}}$ & $1.82 \pm 0.64 \mathrm{~g}$ & $1.53 \pm 1.37 \mathrm{~g}$ & $-0.48 \pm 1.58$ & $\begin{array}{c}\mathrm{F}=20.45 \mathrm{p}=0.00 \\
\mathrm{n} 2=0.59\end{array}$ \\
\hline \multicolumn{9}{|c|}{ Significantly different from: ${ }^{a}-60 ;{ }^{b}-66 ;{ }^{c}-73 ; d-81 ;^{e}-90 ;{ }^{f}-100 ; g>100 \mathrm{~kg}$} \\
\hline
\end{tabular}

Table II. Differences between weight categories of female judokas.

\begin{tabular}{|c|c|c|c|c|c|c|c|c|}
\hline Variable & $\begin{array}{c}-48 \mathrm{a} \\
(\mathrm{n}=9)\end{array}$ & $\begin{array}{l}-52 \mathrm{~b} \\
(\mathrm{n}=7)\end{array}$ & $\begin{array}{c}-57 \mathrm{c} \\
(\mathrm{n}=13)\end{array}$ & $\begin{array}{c}-63 d \\
(n=15)\end{array}$ & $\begin{array}{c}-70 \mathrm{e} \\
(\mathrm{n}=10)\end{array}$ & $\begin{array}{c}-78 \mathrm{f} \\
(\mathrm{n}=8)\end{array}$ & $\begin{array}{l}>78 \mathrm{~g} \\
(\mathrm{n}=16)\end{array}$ & S tatistics \\
\hline Height & $152.84 \pm 5.12$ & $158.33 \pm 2.85$ & $161.96 \pm 4.82^{\mathrm{a}}$ & $163.34 \pm 4.40^{\mathrm{a}}$ & $166.58 \pm 7.99^{\mathrm{a}, \mathrm{b}}$ & $170.21 \pm 7.57 \mathrm{a},{ }^{\mathrm{b}, \mathrm{c}}$ & $172.25 \pm 4.98 \mathrm{a},{ }^{b, c, d}$ & $\begin{array}{c}\mathrm{F}=15.69 \mathrm{p}=0.00 \\
\eta^{2}=0.57\end{array}$ \\
\hline \multicolumn{9}{|l|}{ Skinfold } \\
\hline Triceps & $9.82 \pm 2.95$ & $9.60 \pm 2.14$ & $10.61 \pm 3.08$ & $12.79 \pm 5.27$ & $14.94 \pm 4.55$ & $13.54 \pm 5.96$ & $16.19 \pm 7.04^{\mathrm{a}}$ & $\begin{array}{c}\mathrm{F}=2.98 \mathrm{p}=0.01 \\
\eta^{2}=0.20\end{array}$ \\
\hline Supraspinale & $9.16 \pm 4.70$ & $10.87 \pm 3.88$ & $10.59 \pm 5.85$ & $12.03 \pm 6.85$ & $15.58 \pm 8.77$ & $11.55 \pm 4.51$ & $16.01 \pm 11.88$ & $\begin{array}{c}\mathrm{F}=1.29 \mathrm{p}=0.27 \\
\eta^{2}=0.10\end{array}$ \\
\hline Subscapular & $7.81 \pm 1.98$ & $9.59 \pm 2.44$ & $9.03 \pm 2.01$ & $10.63 \pm 2.92$ & $13.74 \pm 4.29$ & $12.52 \pm 3.15$ & $19.15 \pm 10.52 \mathrm{a},{ }^{\mathrm{b}, \mathrm{c}, \mathrm{d}}$ & $\begin{array}{c}\mathrm{F}=6.58 \mathrm{p}=0.00 \\
\eta^{2}=0.36\end{array}$ \\
\hline Calf & $10.44 \pm 2.65$ & $9.33 \pm 3.32$ & $12.25 \pm 4.01$ & $11.89 \pm 4.72$ & $13.02 \pm 7.69$ & $14.49 \pm 5.56$ & $18.21 \pm 10.78$ & $\begin{array}{c}F=2.38 p=0.04 \\
\eta^{2}=0.17\end{array}$ \\
\hline \multicolumn{9}{|l|}{ Breadth } \\
\hline Humerus & $5.81 \pm 0.99$ & $5.30 \pm 0.64$ & $5.88 \pm 0.40$ & $5.79 \pm 0.46$ & $6.38 \pm 0.29^{b}$ & $6.46 \pm 0.67^{b}$ & $7.02 \pm 0.96^{\mathrm{a}, \mathrm{b}, \mathrm{c}, \mathrm{d}}$ & $\begin{array}{c}\mathrm{F}=8.11 \mathrm{p}=0.00 \\
\eta^{2}=0.41\end{array}$ \\
\hline Femur & $7.60 \pm 1.02$ & $8.03 \pm 0.64$ & $8.62 \pm 0.65$ & $8.79 \pm 0.86$ & $9.13 \pm 0.92^{\mathrm{a}}$ & $9.61 \pm 0.92^{\mathrm{a}, \mathrm{b}}$ & $10.16 \pm 1.34 \mathrm{a}, \mathrm{b}, \mathrm{c}, \mathrm{d}$ & $\begin{array}{c}\mathrm{F}=9.09 \mathrm{p}=0.00 \\
\eta^{2}=0.43\end{array}$ \\
\hline \multicolumn{9}{|l|}{ Girth } \\
\hline Arm & $26.86 \pm 1.68$ & $27.81 \pm 1.45$ & $27.65 \pm 1.27$ & $29.00 \pm 2.23$ & $33.46 \pm 6.34$ & $35.80 \pm 11.13$ & $37.60 \pm 11.47 \mathrm{a},{ }^{\mathrm{b}, \mathrm{c}, \mathrm{d}}$ & $\begin{array}{c}\mathrm{F}=4.83 \mathrm{p}=0.00 \\
\eta^{2}=0.29\end{array}$ \\
\hline Calf & $32.06 \pm 1.38$ & $32.49 \pm 1.60$ & $34.02 \pm 1.68$ & $35.15 \pm 0.89$ & $36.67 \pm 1.25$ & $39.09 \pm 1.64 \mathrm{a}^{\mathrm{b}}$ & $\underset{, \mathrm{f}}{47.05 \pm 8.66 \mathrm{a}, \mathrm{b}, \mathrm{de}}$ & $\begin{array}{c}F=20.78 p=0.00 \\
\eta^{2}=0.64\end{array}$ \\
\hline \multicolumn{9}{|l|}{ Somatotaypes } \\
\hline Endomorphy & $2.95 \pm 0.93$ & $3.22 \pm 0.82$ & $3.15 \pm 0.98$ & $3.59 \pm 1.27$ & $4.30 \pm 1.46$ & $3.70 \pm 1.15$ & $4.40 \pm 1.53$ & $\begin{array}{c}\mathrm{F}=2.41 \mathrm{p}=0.04 \\
\eta^{2}=0.17\end{array}$ \\
\hline Mesomorphy & $3.89 \pm 1.03$ & $3.26 \pm 1.19$ & $3.79 \pm 0.72$ & $4.03 \pm 1.16$ & $5.34 \pm 1.55$ & $6.06 \pm 3.37$ & $8.11 \pm 3.47^{\mathrm{a}, \mathrm{b}, \mathrm{c}, \mathrm{d}, \mathrm{e}}$ & $\begin{array}{c}F=8.40 \mathrm{p}=0.00 \\
\eta=0.42\end{array}$ \\
\hline Ectomorphy & $2.49 \pm 0.94 \mathrm{~g}$ & $2.63 \pm 0.67 \mathrm{~g}$ & $2.45 \pm 1.01^{\mathrm{g}}$ & $1.82 \pm 0.86 \mathrm{~g}$ & $1.27 \pm 1.38$ & $1.08 \pm 1.29$ & $0.10 \pm 1.39$ & $\begin{array}{c}\mathrm{F}=8.37 \mathrm{p}=0.00 \\
\eta^{2}=0.41\end{array}$ \\
\hline
\end{tabular}

Significantly different from: ${ }^{a}-48 ; b-52 ;^{c}-57 ; d-63 ;^{e}-70 ;^{f}-78 ;^{g}>78$ 


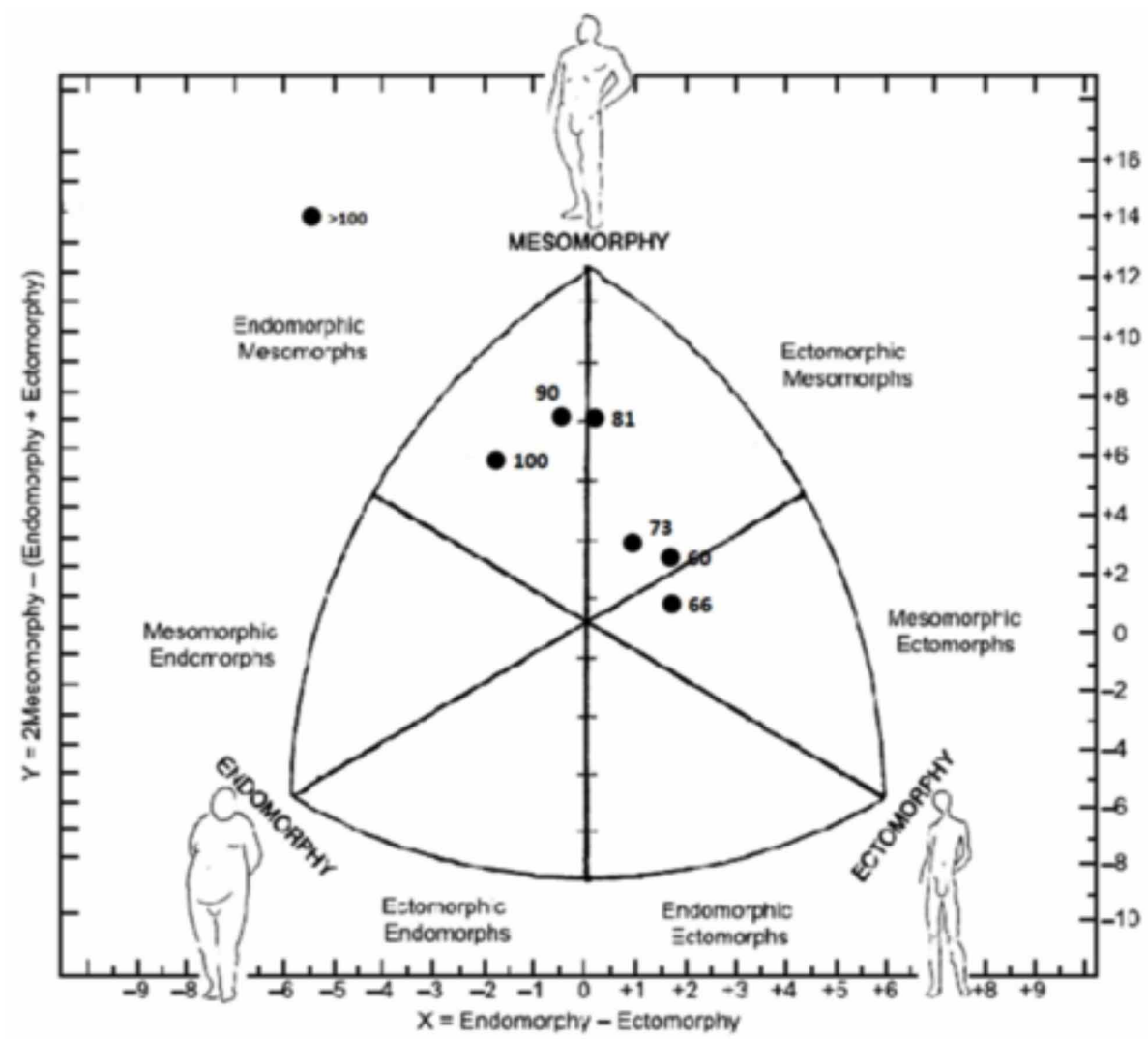

Fig. 1. Somatochart of male judo athletes by weight categories.

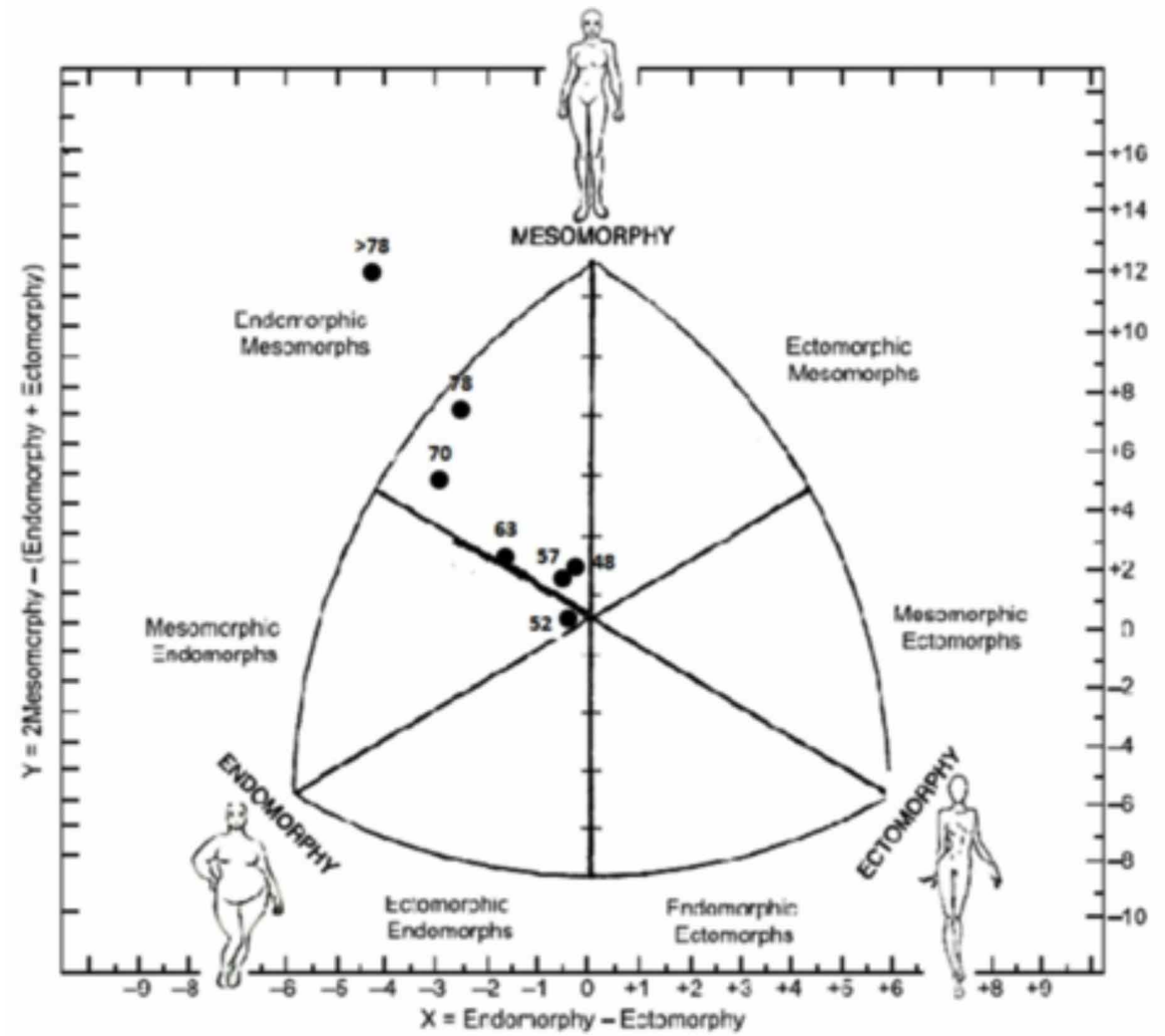

Fig. 2. Somatochart of female judo athletes by weight categories.

\section{DISCUSSION}

In the present study the somatotype profiles of Montenegrin male and female judokas were evaluated in relation to different weight categories. This study has indicated the existence of differences in the anthropometric characteristics and somatotype profiles in relation to different weight categories. The somatotypes of world class judokas in relation to weight categories were very homogeneous. However, the obtained results showed different types of somatotype, especially in male judokas. Also, with an increasing level of competitors in the sport, the value of mesomorphy has increased, while the value of endomorphy has decreased (Noh et al., 2014). The results of the present study showed a linear increase in the anthropometric characteristics from light to heavyweight male and female Montenegrin judokas. Our findings are in line with other studies that compare the anthropometric characteristics of male and female judokas (Claessens et al., 1987; Jagiello, 2013). From among the weight categories, male and female judokas of the heaviest weight categories were distinguished mostly by generally higher anthropometric values (Table I and II). Body structure is known to be related to the accomplishment of an elite level in judo (Franchini et al., 2005). Although somatotypes varied between the different weight categories, mesomorphy was the most predominant somatotype component in elite male athletes (Franchini et al., 2014). Moreover, female judokas had similar components of mesomorphy and endomorphy (Franchini et al., 2011a). However, male athletes showed more variety in terms different somatotype components 
(Fig. 1), with three separate components being observed. Male athletes in the three highest categories were endomorphic mesomorphs $(-90 \mathrm{~kg},-100 \mathrm{~kg}$ and $>100 \mathrm{~kg}$ ) and ectomorphic mesomorphs (-60 kg, $-73 \mathrm{~kg}$ and $-81 \mathrm{~kg}$ ), with judo athletes in the $-66 \mathrm{~kg}$ being mesomorphic ectomorphs. Athletes above $100 \mathrm{~kg}$ had an extreme endomorphic mesomorph rating. A typical somatotype among male judokas is endomorphic mesomorph, with dominant mesomorph and low ectomorph components (Sterkowicz-Przybycien et al., 2012), which was not the case in our study. Recent studies have presented female judoists as mostly endomorphic mesomorph or mesomorph endomorph somatotypes (Kurt et al., 2010; SterkowiczPrzybycien \& Almansba, 2011), which is in line with our results. We observed that the dominant somatotype was endomorphic mesomorph, except for category 52 (Fig. 2). Representatives from the $-52 \mathrm{~kg}$ category were mesomorphic endomorphs. In addition, mesomorphy was the most dominant somatotype component in male and female athletes.

\section{CONCLUSION}

In conclusion, significant differences were observed in the anthropometric characteristics and somatotype profiles of different weight categories. There was a linear increase in anthropometric characteristics from the lightest to heaviest weight category. In the domain of somatotypes, great diversity was noticed in the male athletes. On the contrary, female athletes showed a mainly homogenous somatotype distribution. These data provide a somatotype profile for elite Montenegrin judokas of both genders and enable comparisons with international data. This study highlights how body compositions of national Judo athletes differs between weight categories. It is very likely that some changes could be used in applying proper training methods with a focus on the athletes' physical abilities, which could result in a decrease of somatotype diversity among the weight categories.

\section{ACKNOWLEDGEMENTS}

This work was supported by the Serbian Ministry of Education, Science and Technological Development under Grant [number179011]; Provincial Secretariat for Science and Technological Development under Grant [number142-451-2473] and the Faculty of Sport and Physical Education, University of Novi Sad under Grant [2018 Annual Award].
DRAPSIN, M.; BOJANIC, D.; LJUBOJEVIC, M.; SADRI, F.; JAKSIC, D.; TRIVIC, T. \& DRID, P. Perfiles somatotípicos de judokas Montenegrinos masculinos y femeninos. Int. J. Morphol., 38(5):1244-1249, 2020.

RESUMEN: El objetivo de esta investigación fue establecer las características antropométricas y los perfiles somatotípicos de judokas Montenegrinos de ambos sexos, divididos por categorías de peso. La muestra estuvo compuesta por 170 judokas montenegrinos, 92 hombres $(21,8 \pm 3,9$ años) y 78 mujeres (20,5 $\pm 3,1$ años). Todos los atletas eran de nivel nacional, divididos por categorías de peso oficiales. Este estudio proporcionó datos normativos de perfiles antropométricos y somatotipos en relación con las categorías de sexo y peso de los atletas de judo Montenegrinos. Los perfiles antropométricos cambiaron según la categoría de peso, mientras que los parámetros antropométricos fueron más altos en la categoría más pesadas en comparación con otras categorías. En el dominio de los perfiles de somatotipo masculino, se obtuvieron tres tipos diferentes en relación con la categoría de peso. Las tres categorías fueron mesomorfos endomórficos $(-90 \mathrm{~kg},-100 \mathrm{~kg}$, $>100 \mathrm{~kg})$, mesomorfos ectomórficos (-60 kg, $-73 \mathrm{~kg},-81 \mathrm{~kg}$ ) y ectomorfos mesomórficos (-66 kg). Todas las atletas femeninas fueron mesomorfas endomórficas, excepto la categoría 52. Los representantes de $10 \mathrm{~s}-52 \mathrm{~kg}$ eran endomorfos mesomórficos. Este estudio destaca cómo los perfiles de somatotipo de los atletas nacionales de judo difieren entre las categorías de peso. Es probable que puedan aplicarse algunos cambios en los métodos de entrenamiento, con un enfoque en las habilidades físicas de los atletas, lo que podría resultar en una disminución en la diversidad de somatotipos entre las categorías de peso.

PALABRAS CLAVE: Artes marciales; Judo; Espesor del pliegue cutáneo

\section{REFERENCES}

Busko, K.; Pastuszak, A. \& Kalka, E. Body composition and somatotype of judo athletes and untrained male students as a reference group for comparison in sport. Biomed. Hum. Kinet., 9(1):7-13, 2017.

Carter, J. E. \& Heath, B. H. Somatotyping. Development and Applications. New York, Cambridge University Press, 1990.

Claessens, A.; Beunen, G.; Wellens, R. \& Geldof, G. Somatotype and body structure of world top judoists. J. Sports Med. Phys. Fitness, 27(1):105-13, 1987.

Drid, P.; Casals, C.; Mekic, A.; Radjo, I.; Stojanovic, M. \& Ostojic, S M. Fitness and fitness and anthropometric profiles of international vs. national judo medalists in half-heavyweight category. J. Strength Cond. Res., 29(8):2115-21, 2015.

Drid, P.; Krstulovic, S.; Erceg, M.; Trivic, T.; Stojanovic, M. \& Ostojic, $\mathrm{S}$. The effect of rapid weight loss on body composition and circulating markers of creatine metabolism in judokas. Kinesiology, 51(2):158-60, 2019.

Franchini, E.; Del Vecchio, F. B.; Matsushigue, K. A. \& Artioli, G. G. Physiological profiles of elite judo athletes. Sports Med., 41(2):14766, 2011a. 
Franchini, E.; Sterkowicz-Przybycien, K. \& Takito, M. Y. Anthropometrical profile of judo athletes: comparative analysis between weight categories. Int. J. Morphol., 32(1):36-42, 2014.

Franchini, E.; Takito, M. Y.; Kiss, M. \& Sterkowicz, S. Physical Fitness and Anthropometrical Differences. Biol. Sport, 22(4):315-28, 2005.

Franchini. E.; Brito, C. J. \& Artioli, G. G. Weight loss in combat sports: physiological, psychological and performance effects. J. Int. Soc. Sports Nutr., 9:52, 2012.

Francini, E.; Huertas, J. R.; Sterkowicz, S.; Carratala, V.; GutiérrezGarcía, C. \& Escobar-Molina, R. Anthropometrical profile of elite Spanish judoka: comparative analysis among ages. Arch. Budo, 7(4):239-45, $2011 b$.

Jagiello, W. Differentiation of the body build in judo competitors of the men's Polish national team. Arch. Budo, 9(2):117-25, 2013.

Kurt, C.; Kobas, , I.; Ayas, S.; Dindar, M. D. \& Ömürlü, I. K. The body composition and some conditional features of women judoists of the Turkish National Team. Facta Univ. Phys. Educ. Sport, 8(2):1339, 2010.

Mala, L.; Maly, T.; Camilleri, R.; Dornowski, M.; Zahalka. F.; Petr, M.; Hrasky, P. \& Bujnovsk\$, D. Gender differences in strength lateral asymmetries, limbs morphology and body composition in adolescent judo athletes. Arch. Budo, 13(11):377-85, 2017.

Noh, J. W.; Kim, J. H. \& Kim, J. Somatotype analysis of elite judo athletes compared with nonathletes for health science research. Toxicol. Environ. Health Sci., 6(2):99-105, 2014.

Roklicer, R.; Atanasov, D.; Sadri, F.; Jahic, D.; Bojanic, D.; Ljubojevic, M.; Trivic, T. \& Drid, P. Somatotype of male and female judokas according to weight categories. Biomed. Hum. Kinet., 12:17-24, 2020.

Sterkowicz-Przybycien, K. \& Almansba, R. Sexual dimorphism of anthropometrical measurements in judoists vs untrained subject. Sci. Sports, 26(6):316-23, 2011.

Sterkowicz-Przybycien, K.; Bach, W. \& Zarów, R. Somatotype components in judoists. JCSMA, 3(2):73-8, 2012.

Trivic, T.; Casals, C. \& Drid, P. Physiological responses during arm and leg aerobic power tests in elite female judokas. Exerc. Qual. Life, 8(2):21-4, 2016.

Trivic, T.; Eliseev, S.; Tabakov, S.; Raonic, V.; Casals, C.; Jahic, D.; Jaksic, D. \& Drid, P. Somatotypes and hand-grip strength analysis of elite cadet sambo athletes. Medicine (Baltimore), 99(3):e18819, 2020 .
Corresponding author:

Ass. Prof. Miodrag Drapsin, MD PhD

Medical Faculty

University of Novi Sad

Hajdul Veljkova 3

21000 Novi Sad

SERBIA

Email: miodrag.drapsin@mf.uns.ac.rs

Received: 23-01-2020

Accepted: 29-04-2020 